\title{
Application of Ionizing Radiation in Wastewater Treatment: An Overview
}

\author{
Rehab O. Abdel Rahman $1, *(1)$ and Yung-Tse Hung ${ }^{2}$ \\ 1 Hot Lab. Center, Atomic Energy Authority of Egypt, Cairo P.O. No. 13759, Egypt \\ 2 Department of Civil and Environmental Engineering, Cleveland State University, Cleveland, $\mathrm{OH} 44115$, \\ USA; yungtsehung@gmail.com \\ * Correspondence: alaarehab@yahoo.com; Tel.: +2-010-6140-4462
}

Received: 28 October 2019; Accepted: 18 December 2019; Published: 19 December 2019

\begin{abstract}
Technological applications of nuclear science and technology in different sectors have proved their reliabilities and sustainability over decades. These applications have supported various human civilization needs, ranging from power generation to industrial, medical, and environmental applications. Environmental applications of radiation sources are used to support decision making processes in many fields; including the detection and analysis of pollutant transport, water resources management, and treatment of municipal and industrial wastewaters. This work reviewed recent advances in the research and applications of ionizing radiation in treating different wastewater effluents. The main objective of the work is to highlight the role of ionizing radiation technology in the treatment of complex wastewater effluents generated from various human activities and to address its sustainability. Results of both laboratory and industrial scale applications of this treatment technology have been reviewed, and information on operational safety of industrial irradiators, which affect the sustainability of this technology, has been summarized.
\end{abstract}

Keywords: ionizing radiation; agricultural effluents; dye treatment; pharmaceutical effluents; disinfection

\section{Introduction}

Providing clean water and sanitation is one of the sustainable development goals that were proposed by the United Nation (UN). One of the problems that affect this goal is the reduction of freshwater quality. This reduction is attributed to the continuous increase in untreated wastewaters volumes and poor management practices, which led to the introduction of hazardous materials into freshwater sources [1]. Wastewater is defined, as indicated in UNEP/UN-Habitat, as a combination of one or more of the following effluents: domestic, commercial, industrial, horticultural, aquaculture, and storm water [2]. Recent advances in wastewater management helped in addressing some of the problems in water supply, pollution control, water recycling, and environmental protection. Now wastewaters are proposed as a resource, where many wastewater treatment plants are operated by the biogas generated from the anaerobic digestion of sludge, and the effluents from these plants could be used after appropriate treatment to meet the industrial, agricultural, and potable water requirements. Currently, wastewater management in developing countries is characterized by the discharge of large quantity of wastewater into surface water bodies without proper treatment. It is also challenged by the difficulties to sustain financing, operating and maintaining infrastructure for wastewater treatment.

Conventional wastewater treatment plants (WWTP) aims at reducing the contamination levels to acceptable limits required by the national regulatory agencies and at complying with international guidelines, which allow its safe discharge or reuse. Multi-stages of treatment processes are used, where pre-treatment stage is applied to remove coarse and large solids from the waste stream, using physical treatment technologies such as screens and grit chambers [3]. Primary treatment methods 
are then applied to remove suspended solids that could be settled using gravity sedimentation with or without coagulation and flocculation $[3,4]$. The effluent from the primary treatment is directed to the secondary treatment stage to remove residual suspended solids and organic materials by using biological treatment processes [3]. The effluents from secondary stage contain some heavy metals, synthetic bio-refractory organic pollutants, and soluble microbial products derived during biological treatment [5,6]. The synthetic bio-refractory organic pollutants may include emerging micro-pollutants and disinfection by-products. In the tertiary stage of treatment, the effluents from the secondary stage are polished by removing persistence organic containments and heavy metals using advanced wastewater treatment technologies $[3,4,7]$. These technologies include filtration, sorption, gas stripping, ion-exchange, advanced oxidation processes (AOP), and distillation [7]. Finally, disinfection could be applied depending on the potential use of the treated effluents and the effluents characteristics [3].

Regulations on discharge/reuse indicators varied from country to another. In Denmark, Belgium, Spain, Germany, France, and Netherlands, the regulation covers heavy metals concentrations, total suspended solids (TSS), chemical oxygen demand (COD), 5 days biochemical oxygen demand $\left(\mathrm{BOD}_{5}\right)$, total nitrogen (TN), total phosphorus (TP), and quantity of effluent discharge [8]. On the other hand, toxicity is only considered as reuse/discharge indicator in Germany, France, and United Kingdom [8]. Table 1 lists some international guidelines on the maximum limits for the reuse of effluents containing heavy metals, and U.S. regulation for their reuse and discharge [9-12]. Table 2 presents effluent discharge and reuse quality requirements in USA, Canada, and EU [11,13-15]. It should be noted that three classes of effluents are listed in the Canadian regulation based on the degree of treatment processes used in the treatment plants, namely, A, B and C, that refers to effluent from tertiary and disinfection treatment, tertiary treatment, and secondary treatment, respectively. For reuse regulations in EU, the limit of each class is determined based on the processes used in the treatment plants, irrigation methods, and the type of corps. Class A represents effluents from tertiary and disinfection treatment used any irrigation method and to produce all food corps. Classes B and C are effluent from secondary treatment and disinfection, which are used to produce food and processed food and non-food corps using all irrigation methods, and drip irrigation, respectively. Finally class D in EU regulation represents effluents from secondary treatment and disinfection, where all irrigation methods are allowed to produce industrial, energy, and seed corps [13]. Discharges from un-complied conventional WWTP can lead to the introduction of persistent chemicals and eco-toxic micro-pollutants into the aquatic systems [16]. The incomplete removal of these containments (even in $10^{-9}-10^{-6} \mathrm{~g} / \mathrm{L}$ concentration range) was reported to induce potential long-term detrimental impact on the environment and the human health [17]. Recent research studies reported in the literature supports the application of advanced oxidation processes (AOP) for wastewater treatment to remove these contaminants $[16,17]$.

Table 1. Guidelines of maximum limits for discharge and reuse of some inorganic pollutants in treated wastewater.

\begin{tabular}{|c|c|c|c|c|c|c|c|c|c|}
\hline & \multirow{2}{*}{$\begin{array}{c}\text { WHO, } \\
\text { Reuse, ppb } \\
{[11]}\end{array}$} & \multirow{2}{*}{$\begin{array}{c}\text { FAO, } \\
\text { Reuse, ppb } \\
{[12]}\end{array}$} & \multicolumn{2}{|c|}{ US, ppb [9] } & & \multirow{2}{*}{$\begin{array}{c}\text { WHO, } \\
\text { Reuse, ppb } \\
{[11]}\end{array}$} & \multirow{2}{*}{$\begin{array}{c}\text { FAO, } \\
\text { Reuse, ppb } \\
{[12]}\end{array}$} & \multicolumn{2}{|c|}{ US, ppb [9] } \\
\hline & & & Discharge & Reuse & & & & Discharge & Reuse \\
\hline As & 50 & 100 & 3000 & 50 & $\mathrm{Hg}$ & 1 & $\mathrm{NA}$ & 2000 & 2 \\
\hline $\mathrm{Cd}$ & 5 & 100 & 15,000 & 5 & $\mathrm{Ni}$ & 0 & 200 & 12,000 & 100 \\
\hline $\mathrm{Cr}$ & NA & 100 & 10,000 & 50 & $\mathrm{Ag}$ & NA & NA & 5000 & 50 \\
\hline $\mathrm{Cu}$ & 1 & 200 & 15,000 & NA & $\mathrm{Zn}$ & 5000 & 200 & 25,000 & 5000 \\
\hline $\mathrm{CN}$ & NA & NA & 10,000 & 5.2 & \multirow{2}{*}{$\mathrm{pH}$} & \multirow{2}{*}{$6.5-8.5$} & \multirow{2}{*}{$6.5-8.4$} & \multirow{2}{*}{\multicolumn{2}{|c|}{$6-9$}} \\
\hline $\mathrm{Pb}$ & 50 & 5000 & 40,000 & 50 & & & & & \\
\hline
\end{tabular}


Table 2. Effluent reuse and discharge limits in different regulations [11,13-15].

\begin{tabular}{|c|c|c|c|c|c|c|c|c|c|}
\hline \multirow{3}{*}{ Indicator } & \multirow{2}{*}{\multicolumn{4}{|c|}{$\begin{array}{c}\text { Reuse } \\
\text { EU }[14,15]\end{array}$}} & \multicolumn{5}{|c|}{ Discharge } \\
\hline & & & & & \multirow{2}{*}{$\begin{array}{c}\text { EU } \\
{[14,15]}\end{array}$} & \multirow{2}{*}{$\begin{array}{c}\text { US } \\
{[11]}\end{array}$} & \multicolumn{3}{|c|}{ Canada [13] } \\
\hline & A & B & $\mathrm{C}$ & D & & & A & B & $\mathrm{C}$ \\
\hline $\mathrm{BOD}_{5}, \mathrm{ppm}$ & 10 & \multicolumn{4}{|c|}{25} & 45 & 10 & 10 & 45 \\
\hline TSS, ppm & 10 & \multicolumn{4}{|c|}{35} & 45 & 10 & 10 & 45 \\
\hline COD, ppm & NA & NA & NA & NA & 125 & NA & NA & NA & NA \\
\hline E. coli, $(\mathrm{CFU} / 100 \mathrm{~mL})$ & 10 & $10^{2}$ & $10^{3}$ & $10^{4}$ & NA & 2.2 & 2.2 & 400 & NA \\
\hline Turbidity (NTU) & 5 & NA & NA & NA & NA & 2 & 2 & NA & NA \\
\hline $\mathrm{TN}, \mathrm{ppm}$ & NA & NA & NA & NA & 15 & 10 & 20 & NA & NA \\
\hline
\end{tabular}

AOP use in-situ generated hydroxyl or sulfate radicals for organic pollutants degradation and heavy metals toxicity reduction $[5,18,19]$. AOP convert synthetic organic pollutants and soluble microbial products into simple biodegradable and harmless products, which lead to the reduction of COD and BOD in the treated effluents. AOP technologies employ various activation methods, where induced oxidation is achieved via exposure to photochemical or ionizing radiations, or chemicals $[18,20,21]$. Several studies were conducted to assess the feasibility of using ionizing radiation, in the form of gamma $(\gamma)$ rays or electrons $\left(\mathrm{e}^{-}\right)$, to remove persistence contaminants and to disinfect treated water and sludge. The results of these studies indicated that the ionizing radiation treatment is technically and economically promising. The efficiency of this technology was also proved in the reduction of persistence heavy metals under different treatment conditions. Fifteen pilot plants and several full scale irradiation treatment facilities that employ electron accelerator or $\gamma$ irradiators were established with varying capacities. International Atomic Energy Agency (IAEA) reported that there is a need to continue research in this area to increase the general awareness of these processes in the environmental engineering community [22]. This awareness could be achieved by presenting integrated reviews on the advances in ionizing radiation applications in industrial effluents treatment from technical, operational safety, and economical aspects. Some review papers were published that reviewed the role of ionizing radiation in the degradation of azo dyes [23], summarized the results of the IAEA coordination research project [24], and have reported the optimized doses and procedures [25]. There is a lack in review papers that summarize recent advances in this field and that provide integrated insights into the role of this technology in eliminating hazardous biodegradation and disinfection products. In this work, the effort is directed to summarize the current understanding of the decomposition and removal mechanisms for organic and inorganic pollutants, respectively. Principles and advances in investigating the scientific basis of the applicability of this technique in the treatment and disinfection of agriculture, dyes, pharmaceutical, and petrochemical effluents will be presented. Operational safety and economical factors that affect the sustainability of this technology will be summarized. Finally, knowledge gaps will be identified and research areas that need to be addressed will be highlighted.

\section{Decomposition and Removal Mechanisms}

Generally any emitted radiation is characterized by its ability to deposit some of its energy in the surrounding media. This energy excites the media atoms by striping their electrons or break the chemical bonds between its molecules [26]. This particular characteristic leads to the application of ionizing radiation in treating wastewater, where the radiation imparts some of its energy in the radiolysis of water molecules. The effectiveness of the irradiation process is evaluated by calculating 
the radiation chemical yield (G-value, $\mu \mathrm{mol} \cdot \mathrm{J}^{-}$) that quantifies the number of formed species due to the absorption of $100 \mathrm{eV}$ and is given by:

$$
\mathrm{G}=\frac{6.023 \times 10^{23} \mathrm{C}}{\mathrm{D} \times 6.24 \times 10^{16}}
$$

where $\mathrm{C}$ is the formed species concentration $(\mathrm{mol} / \mathrm{L})$ and $\mathrm{D}$ is the absorbed dose (Gy). Figure 1 illustrates the two stages radiolysis process for water molecules and its corresponding time scale, radiolysis products (primary intermediates), and their G-values. Primary intermediate (PI) then reacts with the pollutants (A) leading to the formation of secondary intermediates (SI) that are less persistence in a bi-molecular reaction to produce the degradation products $(C+D)$, as follows $[25,27,28]$ :

$$
\mathrm{A}+\mathrm{PI} \underset{=}{\rightarrow} \mathrm{SI} \rightarrow \mathrm{C}+\mathrm{D}
$$

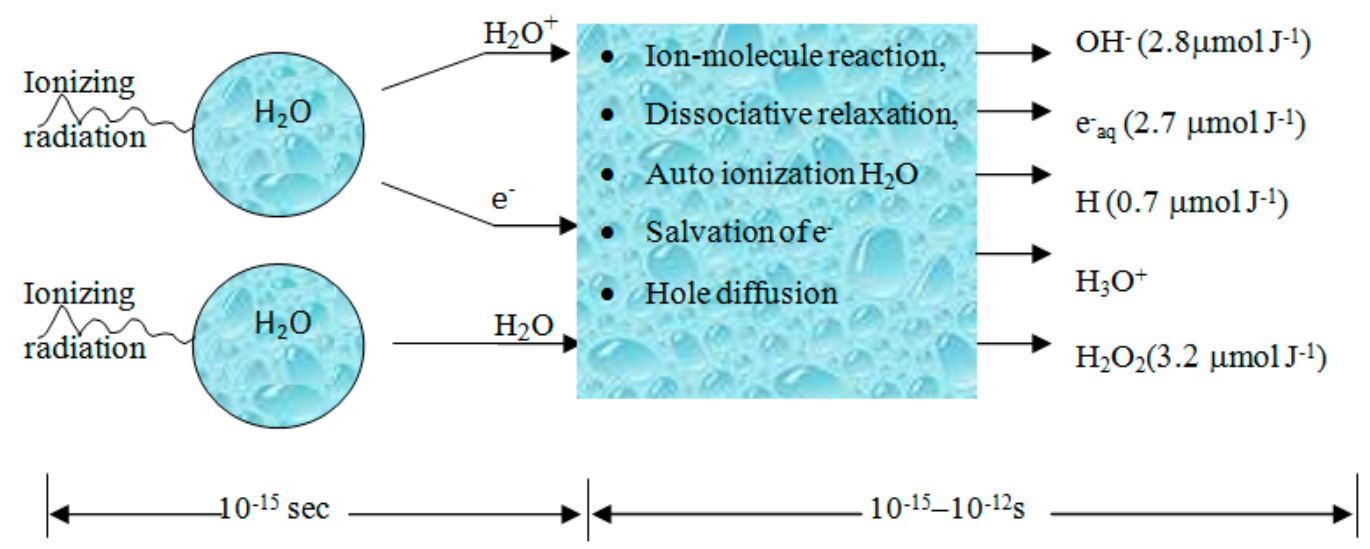

Figure 1. Two stages radiolysis process.

In actual wastewater, there is a competition between the pollutants and the anions in the solution, i.e., $\mathrm{Cl}^{-}, \mathrm{CO}_{3}{ }^{2-}, \mathrm{HCO}_{3}{ }^{-}, \mathrm{SO}_{4}{ }^{2-}$, for the reaction with the primary intermediates. This competition can affect the efficiency of the overall treatment process [27]. Gehringer studied the competition kinetics of two pollutants $(\mathrm{A}, \mathrm{B})$ in wastewater. The reaction rate was attributed to the bi-molecular rate constant $\left(\mathrm{k}_{\mathrm{A}}\right)$ between the solute concentration $([\mathrm{A}]$ or $[\mathrm{B}])$ and the primary intermediates concentration $[\mathrm{OH}]$ as follow:

$$
-\frac{\mathrm{dA}}{\mathrm{dt}}=\mathrm{k}_{\mathrm{A}}[\mathrm{A}][\mathrm{OH}]
$$

Table 3 lists the bi-molecular reaction rate constants for some pollutants $[22,25,27,29]$. The amount of the specific radicals available for interaction with certain solute could be calculated using the reaction probability $\left(\mathrm{P}_{\mathrm{A}}\right)$ according to the following equation:

$$
\mathrm{P}_{\mathrm{A}}=\frac{\mathrm{k}_{\mathrm{A}}[\mathrm{A}]}{\mathrm{k}_{\mathrm{A}}[\mathrm{A}]+\mathrm{k}_{\mathrm{B}}[\mathrm{B}]}
$$

Figure 2 illustrates the reactions between the primary intermediates and the available anions in the wastewater effluents. Wojnarovits and Takacs [30] indicated that intermediate reaction with chloride ions is dominant at $\mathrm{pH}<5$, whereas the reaction with carbonate and bicarbonate ions are dominant at neutral or slightly alkaline $\mathrm{pH}$. The produced free radicals will subsequently react with dissolved organic matters in the wastewater via direct electron transfer (outer sphere electron), addition to double bonds (inner sphere electron) or abstraction of $\mathrm{H}$-atoms from $\mathrm{C}-\mathrm{H}$ bonds. The last reaction takes place between oxidizing radicals and saturated molecules. It should be noted that in some cases, it is very hard to determine if the reaction is electron transfer or radical addition/elimination. 
Table 3. Bimolecular reaction rate constants for some pollutants $[22,25,27,29]$.

\begin{tabular}{|c|c|c|c|c|c|c|c|}
\hline \multirow{2}{*}{ Compound } & \multicolumn{3}{|c|}{ Rate Constant, $\mathrm{M}^{-1} \mathrm{~s}^{-1}, \times 10^{9}$} & \multirow{2}{*}{ Compound } & \multicolumn{3}{|c|}{ Rate Constant, $\mathbf{M}^{-1} \mathrm{~s}^{-1}, \times 10^{9}$} \\
\hline & $\mathrm{OH}$ & $\mathbf{e}^{-}$ & $\mathbf{H}$ & & $\mathrm{OH}$ & $\mathbf{e}^{-}$ & $\mathbf{H}$ \\
\hline Perchloroethylene & 1.7 & 13 & & Bicarbonate & 0.0085 & & $4 \times 10^{-3}$ \\
\hline Trichloroethylene & 2.6 & 19 & & Nitrogen & & 9.7 & \\
\hline Dichloroethylene & 7 & 7.5 & & Oxygen & & 19 & \\
\hline Vinylchloride & 12 & 0.25 & & $\begin{array}{l}\text { Methyl t-butyl } \\
\text { ether }\end{array}$ & 2 & 0.018 & \\
\hline 1,1,1-Trichloroethane & 0.04 & & & $\begin{array}{l}\text { Ethyl t-butyl } \\
\text { Ether }\end{array}$ & 1.8 & 0.01 & $7 \times 10^{-3}$ \\
\hline Chloroform & 0.005 & 30 & & $\begin{array}{l}\text { Diisopropyl } \\
\text { Ether }\end{array}$ & 2.5 & $7 \times 10^{-3}$ & 0.067 \\
\hline T-Amyl Methyl Ether & 2.4 & $3 \times 10^{-3}$ & $3 \times 10^{-3}$ & Acetylenes & $0.1-1$ & & \\
\hline Alcohols & $0.1-1$ & & & Aldehydes & 1 & & \\
\hline Alkanes & $0.001-1$ & & & Aromatics & $0.1-100$ & & \\
\hline Carboxyl Acids & $0.01-1$ & & & Ketones & 1 & & \\
\hline Organo-Nitrogen & $0.1-100$ & & & Olefins & $1-10$ & & \\
\hline Phenols & $1-10$ & & & Organo-Sulfure & $1-10$ & & \\
\hline $\begin{array}{c}\text { Trichloronitromethane } \\
\text { (TCNM), } \\
\text { Chloropicrin }\end{array}$ & $0.0497 \pm 0.28$ & $21.3 \pm 0.03$ & & Carbofuran & 6.6 & & \\
\hline Benzene & 7.8 & & & Carbendazim & 2.2 & & \\
\hline
\end{tabular}

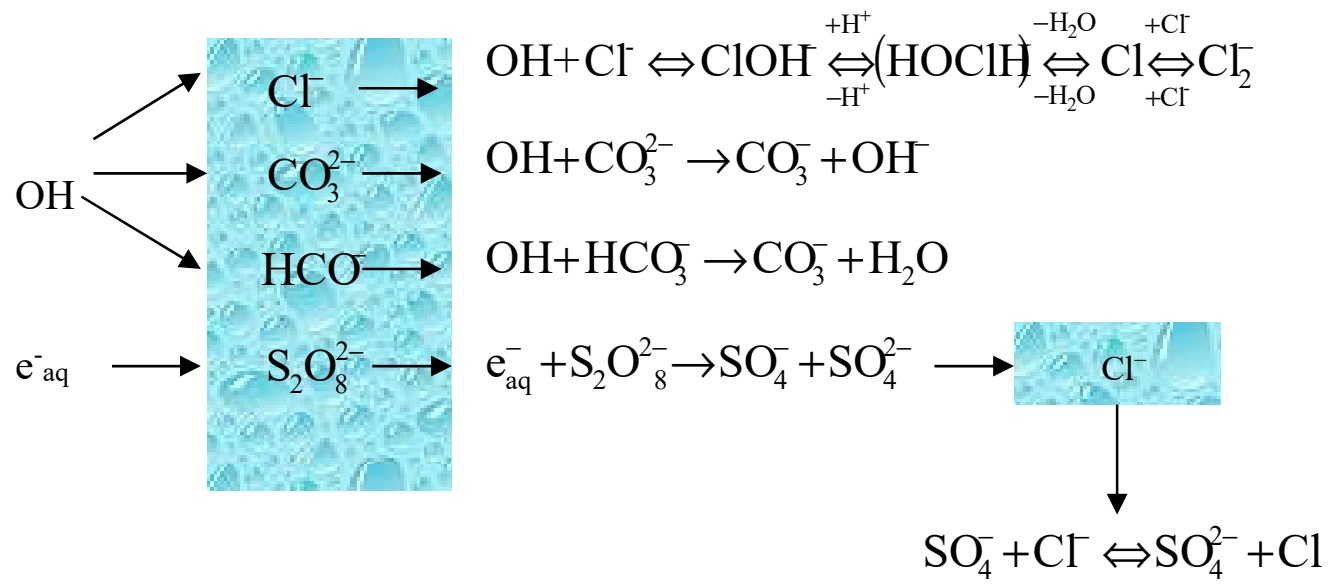

Figure 2. Schematic diagram of intermediate reaction with free radicals.

Ionizing radiation can reduce various forms of mercury via reaction with $\mathrm{e}^{-}$aq (Equation (5)) and $\mathrm{H}$ (Equation (6)) to form unstable compound that dimerized (Equation (7)) to produce insoluble form $[31,32]$.

$$
\begin{gathered}
\mathrm{HgCl}_{2}+\mathrm{e}_{\mathrm{aq}}^{-} \rightarrow \mathrm{HgCl}+\mathrm{Cl}^{-} \\
\mathrm{HgCl}_{2}+\mathrm{H} \rightarrow \mathrm{HgCl}+\mathrm{Cl}^{-}+\mathrm{H}^{+} \\
2 \mathrm{HgCl}_{2} \rightarrow \mathrm{Hg}_{2} \mathrm{Cl}_{2}
\end{gathered}
$$

The presence of hydroxyl radicals inhibited the production of insoluble mercury $\left(\mathrm{Hg}_{2} \mathrm{Cl}_{2}\right)$ through re-oxidation of $\mathrm{HgCl}$ [31]. To enhance the removal performance of this technology the use of organic radical to act as hydroxyl scavenger was proposed. For example, ethanol may be used (Equations (8) and (9)) with the following reactions [9]: 


$$
\begin{gathered}
\mathrm{CH}_{3} \mathrm{CH}_{2} \mathrm{OH}+\mathrm{OH} \rightarrow \mathrm{CH}_{3} \mathrm{CHOH}+\mathrm{H}_{2} \mathrm{O} \\
\mathrm{HgCl}_{2}+\mathrm{CH}_{3} \mathrm{CHOH} \rightarrow \mathrm{HgCl}+\mathrm{Cl}^{-}+\mathrm{CH}_{3} \mathrm{CHO}+\mathrm{H}^{+}
\end{gathered}
$$

Successive reduction of $\mathrm{Cr}$ species from (VI) state to (III) state is achieved via reaction with $\mathrm{H}$ [32]. On the other hand, cadmium (II) and lead (II) are reduced via reaction with $\mathrm{H}$ or/and $\mathrm{e}^{-}$aq (Equation (10)) to produce $\mathrm{Cd}(\mathrm{I})$ that undergoes disprotonation (Equation (11)) or oxidization through a reaction with $\mathrm{OH}^{-}$or $\mathrm{H}_{2} \mathrm{O}_{2}$ (Equation (12)), or react with hydrogen to produce unstable $\mathrm{MH}^{+}$species that decay (Equation (13)) [18].

$$
\begin{gathered}
\mathrm{M}^{2+}+\mathrm{e}_{\mathrm{aq}}^{-} \rightarrow \mathrm{M}^{+} \\
2 \mathrm{M}^{+} \rightarrow \mathrm{M}+\mathrm{M}^{2+} \\
\mathrm{M}^{+}+\mathrm{OH} \rightarrow \mathrm{M}^{2+}+\mathrm{OH}^{-} \\
2 \mathrm{H}+2 \mathrm{M}^{+} \rightarrow 2 \mathrm{MH}^{+} \rightarrow \mathrm{H}_{2}+\mathrm{M}^{2+}+\mathrm{M}
\end{gathered}
$$

To reduce the oxidation effect and subsequently to enhance cadmium and lead precipitation, an organic $\mathrm{OH}^{-}$scavenger could be used or the process could be operated in the absence of oxygen [31-33].

\section{Advances in Treating Agricultural Wastewaters}

Despite chemical pesticides, herbicides, and fungicides are applied according to national agricultural guidelines to enhance the agricultural production efficiency. Residues of these persistence pollutants and their toxic byproducts exist in agricultural wastewater, and could migrate to surface-and ground-waters. Ionizing radiation treatment technology proved its effectiveness in decomposing a varied number of these pollutants using tertiary treatment method. Most of the researches conducted

\begin{tabular}{|c|c|c|c|c|c|}
\hline Pollutant & Origin & $\begin{array}{l}\text { Degradation } \\
\text { Performance }\end{array}$ & $\begin{array}{l}\text { Initial Contaminant } \\
\text { Concentration, ppm }\end{array}$ & Dose, KGy & References \\
\hline $\begin{array}{l}\text { Polychlorinated } \\
\text { Biphenyls (PCB) }\end{array}$ & Pesticide & $96 \%$ & NA & $<0.1$ & [34] \\
\hline Alkali Halides & $\begin{array}{l}\text { Herbicides, } \\
\text { fungicides, } \\
\text { insecticide }\end{array}$ & $98 \%$ & 100 & 1 & [25] \\
\hline \multirow{3}{*}{ Trihalomethanes } & \multirow{3}{*}{$\begin{array}{l}\text { Disinfection by } \\
\text { products }\end{array}$} & $87.4 \%$ & NA & 2 & [25] \\
\hline & & $95 \%$ & $145-780$ & 6 & [35] \\
\hline & & $87.8 \%$ & 264 & 8 & [35] \\
\hline Nitrophenols & $\begin{array}{l}\text { Degradation } \\
\text { products }\end{array}$ & & 0.139 & 5 & [25] \\
\hline $\begin{array}{l}\text { Carbofuran, } \\
\text { Dimethoate, } \\
\text { Imidacloprid, } \\
\text { Procloraz }\end{array}$ & Pesticide & $99 \%$ & 50, (pH 5.5) & 5 & [36] \\
\hline Methiocarb & Pesticide & $67 \%$ & & & [36] \\
\hline 2,4-Dichlorophenol & Pesticide & $\begin{array}{l}\text { Complete } \\
\text { degradation }\end{array}$ & 50 & 10 & [22] \\
\hline
\end{tabular}
in this area focused on optimizing the irradiation conditions, investigating the effect of other waste components on the degradation process, and the possibility of using combined treatment technologies to enhance the overall efficiency of the treatment process. Table 4 summarizes the performance of ionizing radiation in removing some pollutants in agricultural wastewaters.

Table 4. Performance of agricultural wastewater pollutants degradation using irradiation.

NA: Not Available. 
The optimal irradiation conditions for six commercial pesticides, i.e., diazinon, dimethoate, procloraz, metiocarb, imidacloprid, and carbofuran, using electron-beam facility, were determined for different wastewater compositions and at different operational conditions [36]. The initial pesticide concentrations $\left(\mathrm{C}_{\mathrm{i}}\right)$ varied in the range $40<\mathrm{C}_{\mathrm{i}}<400 \mathrm{ppm}$, the initial $\mathrm{pH}$ in the range $(4.5<\mathrm{pH}<8)$ and the irradiation doses were varied from 2-10 KGy. The application of $5 \mathrm{KGy}$ was found to be the most efficient for the treatment of procloraz, dimethoate, imidacloprid, and carbofuran $(99 \%$ degradation), but not efficient for the treatment of metiocarb. Low irradiation doses ( $<1 \mathrm{KGy}$ ) led to the formation of hydroxylated intermediates that build-up in the solution with the progress of the irradiation process. By increasing the irradiation period, a complete removal of the pollutants is achieved as a result of hydroxylation of the accumulated intermediates. The effect of the combined process of aeration and irradiation treatment was evaluated. It was found that the use of aeration can improve the metiocarb removal by $18 \%$. In general, the hydroxylation of the aromatic ring to produce hydroxyl-cyclohexadienyl radicals is reversible [37]. Using aeration to inhibit the formation of these reversible radicals by peroxidation will lead to more efficient degradation [37]. The optimum irradiation conditions for the degradation of three herbicide and one fungicide, i.e., 2,4-dichlorophenoxyacetic acid (2,4-D), 3,6-dichloro-2-methoxy-benzoic acid (dicamba), 4-chloro-2-methylphenoxyacetic acid (MCPA), and carbendazim were determined. It was found that complete radiolytic degradation of dicamba $\left(C_{i}=110 \mathrm{ppm}\right)$ is achieved using an irradiation dose of $5 \mathrm{KGy}$ and the process is insensitive to the presence of other waste constituents, i.e., $\mathrm{NO}_{3}{ }^{-}$. 2,4-D-degradation was found to be affected by the presence of other waste constituents [35]. Another study addressed the use of ionizing radiation in the treatment of 2,4-D, and MCPA at lower concentration levels ( $<50 \mathrm{ppm}$ ), in the presence $\mathrm{Cl}^{-}, \mathrm{Br}^{-}$and $\mathrm{NO}_{3}{ }^{-}$. The results confirmed the role of oxidative radicals $\left(\mathrm{OH}^{-}\right)$in the degradation of these pollutants and the sensitivity of the irradiation process to the presence of the anions, where the secondary intermediate formed at low doses ( $<1$ KGy) are more toxic than the original pollutants [38,39].

The feasibility of using ionizing radiation in the treatment of agricultural effluents containing chlorinated organic pesticide, i.e., (4-chloro phenoxyacetic acid (4-CPA), 2.4-dichlorophenoxyacetic acid (2,4-D), 2.4-dichlorophenoxyacetic propionic acid (2,4-DP), and 2.4-dichlorophenoxyacetic butanoic acid (2,4-DB) was studied. The results indicated good efficiency of the irradiation process at $1 \mathrm{KGy}$ in decomposing these pollutants. It was observed that chlorine was released as a result of their degradation. To reduce the disinfection byproducts in the treated wastewater prior to its use in chicken and fish livestock, an irradiation of the wastewater stream at $16.2 \mathrm{KGy}$ dose was proposed, and $27 \mathrm{KGy}$ was proposed for sludge treatment [40].

Swine wastewaters, which are alkaline agricultural wastewaters, that contain different pollutants, i.e., carbohydrates, proteins, lipids nitrates, nitrite, phosphate, and ammonia, were treated using a combined process of irradiation and ion-exchange biological treatment method. The use of electron-beam at $75 \mathrm{KGy}$ achieved $85.1 \%$ removal efficiency of chemical oxygen demand (COD) at organic loading rate of $1.41 \mathrm{~kg} / \mathrm{m}^{3}$.day and achieved $75 \%$ removal efficiency of total nitrogen. The nitrogen removal was found to be sensitive to variation in current density [41].

\section{Advance in Dyes Treatments}

The presence of organic dyes in industrial effluents can lead to serious health and environmental problems. Ionizing radiation treatment was proposed to remove these contaminants. Research efforts were directed to study model compounds, single polluted solution, simulated wastewater, and real effluents. Table 5 summarizes the kinetic reactions of model compounds with their primary intermediates, their corresponding rate coefficients and their secondary intermediates [23]. Most of these compounds, except Azobenzene, decompose as a result of hydroxylation reaction, where the rate coefficients are slightly varied depending on the molecular structure of the contaminant. On the other hand, reactions with $\mathrm{e}^{-}$and $\mathrm{H}$ have small contribution to the decomposition process [23]. G value for phenol degradation was found to be inversely proportional to the irradiation dose. Degradation reaction is first order and favors neutral $\mathrm{pH}$. Phenol degradation is enhanced with the addition of 
oxidants, i.e., $\mathrm{O}_{3}$, or $\mathrm{S}_{2} \mathrm{O}_{8}{ }^{2-}$. $\mathrm{S}_{2} \mathrm{O}_{8}{ }^{2-}$ was more efficient due to the selectivity of $\mathrm{SO}_{4}{ }^{2-}$ radical to the formed by-products (carboxylic acids) [42].

Table 5. Degradationkinetics of model compounds [23].

\begin{tabular}{cccc}
\hline Model Compound & $\begin{array}{c}\text { Primary } \\
\text { Intermediate }\end{array}$ & $\begin{array}{c}\text { Rate Coefficient, } \\
\times \mathbf{1 0} \mathbf{1 0} \mathbf{~ m o l}^{\mathbf{- 1}} \cdot \mathbf{L} \cdot \mathbf{s}^{\mathbf{- 1}}\end{array}$ & Secondary Intermediate \\
\cline { 2 - 4 } Aniline & $\mathrm{OH}^{-}$ & $0.86-1$ & - \\
\hline Phenol & $\mathrm{H}^{+}$ & 0.2 & $\begin{array}{c}\text { Anilino radical (directly } \\
\text { and after water } \\
\text { elimination.) }\end{array}$ \\
\hline Atrazine & $\mathrm{OH}^{-}$ & $0.66-1.4$ & $\begin{array}{c}\text { Cyclohexadienyl-type } \\
\text { radical }\end{array}$ \\
\hline Azobenzene & $\mathrm{H}^{+}$ & 0.17 & Hydrazyl radicals \\
\hline 4-amino-5-hydroxynaphthalene- & $\mathrm{OH}^{-}$ & 0.24 & Anilino-type \\
2,7-disulphonic acid & $\mathrm{e}^{-}$ & $1-3.3$ & \\
\hline
\end{tabular}

$65 \%$ de-coloration of aqueous solution containing Alizarin Yellow GG (AY-GG, $C_{i}=100 \mathrm{ppm}$ ) was achieved using $9 \mathrm{KGy}$ dose. Irradiation pre-biodegradation was proposed to improve the efficiency of treatment by $30 \%$ due to the formation of heterocyclic aromatic amines and cyanides. Increasing the irradiation dose can enhance the biodegradation due to the elimination of toxic secondary intermediates [43]. The aqueous solutions of Reactive Blue 15 (RB15) and Reactive Black 5 (RB5) dyes were irradiated with doses $0.1-15 \mathrm{KGy}$ and at 2.87 and $0.14 \mathrm{KGy} / \mathrm{h}$ dose rates. Complete de-coloration was observed at 1 and $15 \mathrm{KGy}$ doses for RB5 and RB15, respectively [25]. The de-coloration mechanisms for Apollofix Red (AR) and RB5 in aqueous solutions were investigated using $\gamma$-rays irradiation [44]. It was found that the de-coloration that was due to reactions with $\mathrm{e}^{-}$and $\mathrm{H}$, and increased linearly with increasing the irradiation dose, whereas de-coloration that was due to reaction with $\mathrm{OH}^{-}$radical increase logarithmically. De-coloration was attributed to the destruction of the color bearing part of the dye as a consequence of $\mathrm{OH}^{-}$addition to the aromatic ring [25]. Aqueous solutions containing AR and Apollofix Yellow (AY) were irradiated with doses of 1.0-8.0 KGy and at 0.14 KGy/h dose rate. The complete de-coloration was observed using 3.0 and 1.0 KGy doses for AR and AY, respectively [25].

The use of ionizing radiation to decompose wastewater effluents of varying $\mathrm{pH}(1.6<\mathrm{pH}<11.5)$ and COD concentration $\left(650<\mathrm{C}_{\mathrm{i}}<2210 \mathrm{ppm}\right)$ from dye manufacturing factory was evaluated [45]. The use of $15 \mathrm{KGy}$ decreased the optical density by $95 \%$ and removed COD by $72 \%$. Use of aeration and $\mathrm{H}_{2} \mathrm{O}_{2}$ enhanced the degradation. The treatment of simulated wastewater contains four dyes, i.e., direct and reactive azo and anthraquinone dyes, using electron beam and $\gamma$ radiation at different dyes concentration and irradiation doses in the presence and absence of $\mathrm{H}_{2} \mathrm{O}_{2}$ was studied [46]. The highest de-coloration performance $(\approx 100 \%)$ was obtained via electron beam irradiation using $7 \mathrm{KGy}$ for direct and reactive azo dye $\left(\mathrm{C}_{\mathrm{i}}=1000 \mathrm{ppm}\right)$. A combined process of electron-beam and biological treatment was used in a pilot plant study in treating two waste streams. The first stream was generated during the operation of dying process and the second stream was from polyester fiber production enriched with ethylene glycol and terephthalic acid in 1998. An industrial facility was later commissioned and operated based on the same technology in 2005 [24,25]. The use of electron-beam technology to de-color and detoxify three effluents that represent chemical, final, and standard textile effluents was conducted. The effluents were de-colored (96, 55, and 90\%) using 40, 2.5, and $2.5 \mathrm{KGy}$, respectively. The use of irradiation pre-biological treatment was found to reduce the toxic effect to the subsequent biological treatment process [47]. The potential use of combined treatment for alkaline and 
nearly neutral textile effluent of COD (632 < COD < 127 ppm), BOD $(311<$ BOD < 490 ppm $)$, and turbidity $(75-77 \%)$ at irradiation doses ( $<3 \mathrm{KGy})$ was investigated. It was found that the application of coagulation prior to irradiation enhanced the de-coloration performance [48]. Electron beam irradiation of simulated effluents that contains reactive dye (reactive yellow 15), size (starch), synthetic size (PVA), alkali, color, and pigment (pigment red 139) was studied [49]. Application of $1 \mathrm{KGy}$ irradiation for post-biodegradation treatment enhanced the quality of the treated effluents.

\section{Advances in Wastewater and Sludge Disinfection}

Disinfection of treated wastewaters using ionizing radiation has been studied extensively. The application of $4 \mathrm{KGy}$ reduced the $\mathrm{BOD}_{5}, \mathrm{COD}$, and total organic carbon (TOC) to acceptable limits [50]. In another study, anaerobic digested sludge irradiation at $1 \mathrm{KGy}$ eliminated $98 \%$ of the total and fecal coliform, whereas $\mathrm{BOD}_{5}$ was reduced to an acceptable limit at $4 \mathrm{KGy}$ and COD was not affected by irradiation up to $20 \mathrm{KGy}$ [44]. The disinfection of acidic industrial effluents and sludge $(2<\mathrm{pH}<3)$ of high concentration of $\mathrm{BOD}_{5}$ and $\operatorname{COD}(7093$, and 32,664 ppm, respectively) using $\gamma$ irradiation was investigated [17]. Sludge and treated water disinfection could be achieved using 7 and 4 KGy, respectively, whereas the reduction of the $\mathrm{BOD}_{5}$ and $\mathrm{COD}$ concentration to acceptable limits was obtained at $18 \mathrm{KGy}$. A comparative study was conducted to evaluate the use of different advanced oxidation methods in the disinfection of the municipal wastewater, re-growth control, and the associated operating costs [51]. The results revealed that UV efficiency was affected by the seasonal variation in the wastewater composition, whereas ionizing radiation efficiency was respectively unaffected by this factor. Ionizing radiation provided high stable disinfection efficiency (95\%) for the total colony count and total coliform at radiation doses $>0.25 \mathrm{KGy}$ and inhibited the re-growth. From economical point of view, the electric power consumption for UV and ozone is three orders of magnitude higher than that required for ionizing radiation. Electron beam irradiation used to disinfect a municipal wastewater at irradiation doses (<3 KGy) and removed $90 \%$ of coliforms [51].

\section{Advances in Pharmaceutical and Petrochemical Wastewater Treatments}

The possibility of treating pharmaceutical effluents was addressed by studying the effect of ionizing radiation on the biodegradability and toxicity of individual drugs. Changes in biodegradability and toxicity induced in aqueous solutions containing sulfamethoxazole $\left(\mathrm{SMX}, \mathrm{C}_{\mathrm{i}}=0.1 \mathrm{mmol} / \mathrm{L}\right) \mathrm{using}$ ionizing radiation treatment revealed that SMX biodegradability was improved by applying $0.4 \mathrm{KGy}$ dose. At 2.5 KGy dose, SMX conversion to biologically treatable substances was noted [52]. The degradation of carbamazepine (CBZ) by ionizing radiation was enhanced by the application of oxidant, $10 \mathrm{mM} \mathrm{H}_{2} \mathrm{O}_{2}$ [20]. The decomposition of mutagenic and carcinogenic secondary intermediates, i.e., acridine (ACIN), was enhanced in the presence of $\mathrm{H}_{2} \mathrm{O}_{2}$. The ionization of aqueous solutions containing ciprofloxacin (CIR) and norfloxacin (NOR) $\left(\mathrm{C}_{\mathrm{i}}=10^{-4} \mathrm{M}\right)$ was investigated. The degradation reaction proceeds via $\mathrm{OH}^{-}$and $\mathrm{e}^{-}$reactions with comparable rate constant $\left(\approx 10^{9} \mathrm{~mol}^{-1} \cdot \mathrm{L} \cdot \mathrm{s}^{-1}\right)$. At low irradiation doses, the antibacterial activities of the secondary intermediates vanished. Pollutants hydroxylation during $\gamma$ irradiations proceeds on the hydroxylated molecules and desethylene derivatives and during pulse radiolysis is attributed to absorbance of hydroxyl-cyclohexadienyl radicals. In hydrated electron reactions, electron adduct is formed then it underwent protonation yielding cyclohexadienyl type radical [53]. The treatment of real pharmaceutical effluent using combined process of coagulation, biological treatment, and $\gamma$ irradiation was investigated [54]. Two tested neutral effluents, namely, low organic strength (LSW; BOD < 6730 ppm, COD < 12,715 ppm) and high organic strength (HSW; $\mathrm{BOD}<27,242, \mathrm{COD}<51,223 \mathrm{ppm})$. The use of irradiation led to maximum reduction in COD of $45 \%$ in acidic media at $50 \mathrm{KGy}$ (LSW) and 30\% in acidic media at $100 \mathrm{KGy}$ (HSW). The application of coagulation pre-treatment was found to affect the efficiency, where $55 \%$ and $50 \%$ could be achieved using $100 \mathrm{KGy}$, for LSW and HSW, respectively. The use of $\mathrm{H}_{2} \mathrm{O}_{2}$ led to enhanced COD and TOC removal efficiency, when compared to $\mathrm{S}_{2} \mathrm{O}_{8}{ }^{2-}$. The combined treatment led to overall $92.7 \% \pm 2.3 \%$ and $90.2 \% \pm 2.9 \%$ removal of COD from LSW and HSW, respectively. In a separate study, combined 
process of coagulation, electron beam treatment, and biological treatment was performed. An overall reduction in COD of $94 \%$ and $89 \%$ was achieved LSW and HSW, respectively [55]. The radiation doses were varied from $25-100 \mathrm{KGy}$ at different $\mathrm{pH}$ that represent acidic, neutral and alkaline media. The slightly improved performance of the electron irradiation process was related to the reaction of $\mathrm{e}^{-}$aq with $\mathrm{H}$ through parallel reaction with the organic contaminants to generate $\mathrm{H}^{+}$, which subsequently inhabits the recombination of $\mathrm{e}^{-}$aq and $\mathrm{OH}^{-}$. The consideration of the total cost of electron beam irradiation facility $(20 \mathrm{MeV}, 100 \mathrm{~kW})$, its shielding and maintenance, and capital costs was estimated and the cost of the treatment was estimated to be $0.6 \mathrm{USD} / \mathrm{m}^{-3}$.

The decomposition of naphthalene $\left(\mathrm{C}_{\mathrm{i}}=5-32 \mathrm{ppm}\right)$ in aqueous solution was studied using $\gamma$ irradiation combined with both $\mathrm{H}_{2} \mathrm{O}_{2}$ and $\mathrm{TiO}_{2}$ nano-particles. The application of $3 \mathrm{KGy}$ dose led to high naphthalene removal performance $(>98 \%)$ and TOC reduction $(28-31 \%)$ due to hydroxylation reaction. This performance is enhanced by $35 \%$ due to the presence of $40 \mathrm{ppm}$ of $\mathrm{H}_{2} \mathrm{O}_{2}$ and $48 \%$ due to the presence of $0.8 \mathrm{~g} / \mathrm{L} \mathrm{TiO}_{2}[56]$.

\section{Sustainability of the Technology}

In general, the sustainability of the nuclear industry is governed by its technical competitive performance, economical feasibility, and safe operational practice. As presented in the previous sections, the technical performance of the application of ionizing radiation technology in wastewater treatment is effective in disinfection and reduces the bio-refractory nature of several persistence organic pollutants. Several studies proved the economical feasibility of the e-beam and $\gamma$ irradiation technologies [21,32,41,48,51,54-63]. For e-beam technology, the capital costs include the accelerator price, building shield, conveyer, cooling and ventilation systems, and monitoring system [57]. The capital cost of the e-beam accelerator is dependent on the power $(\mathrm{P}, \mathrm{kW})$ consumed to produce optimum dose $(D, K G y)$ for specified plant flow rate $\left(Q, \mathrm{~m}^{3} / \mathrm{h}\right)$ taking into account the utilization factor $(\varphi)[48,60]$ :

$$
\mathrm{p}=\frac{\mathrm{DQ}}{\varphi}
$$

The cost of the accelerator installation $\left(\mathrm{K}_{\mathrm{i}}, \mathrm{k} \$\right)$ is determined using the applied electron energy $(\mathrm{E}, \mathrm{MeV})$, power, accelerator type and manufacturer $(\mathrm{b}, \mathrm{d})$, and installation coefficient $(\mathrm{a})$ as follows [48,57]:

$$
K_{i}=a \cdot b(1 \pm d) E \sqrt{p}
$$

The values of the coefficients $b$ and $d$ varied with time due to the evolution and advances in the manufacturing process [48]. On the other hand, the costs of $\gamma$ irradiator are not accompanied by power consumption [54], where $\gamma$ source irradiate spontaneously. The average cost (ATC, $\mathrm{k} \$ / \mathrm{m}^{3}$ ) of this irradiation technique is determined based on the price of the used radioactive source $\left(R, k \$ / C_{i}\right)$, required activity $\left(\mathrm{I}, \mathrm{C}_{\mathrm{i}}\right)$, irradiation time $(\mathrm{t}, \mathrm{h})$ and half life $\left(\mathrm{t}_{0.5}, \mathrm{~h}\right)$, and the irradiation chamber volume $\left(\mathrm{v}, \mathrm{m}^{3}\right)$

$$
\mathrm{A}\left(\mathrm{C}_{\mathrm{i}}\right)=\mathrm{R} \times \mathrm{I} \times \mathrm{t} /\left(\mathrm{t}_{0.5} \times \mathrm{v}\right)
$$

To facilitate the cost comparison between the use of e-beam technology and other treatment technologies the relative treatment costs estimated at different time is presented in Figure $3[48,64]$. In terms of cost, only disinfection process, which uses chlorine, is better than the use of e-beam technology. Similar data are not available for $\gamma$ irradiation. To compare the cost of this technique alone and cost of this technology combined with coagulation, the data reported by Changotra et al. [54] were plotted for two types of industrial effluents (Figure 4). 


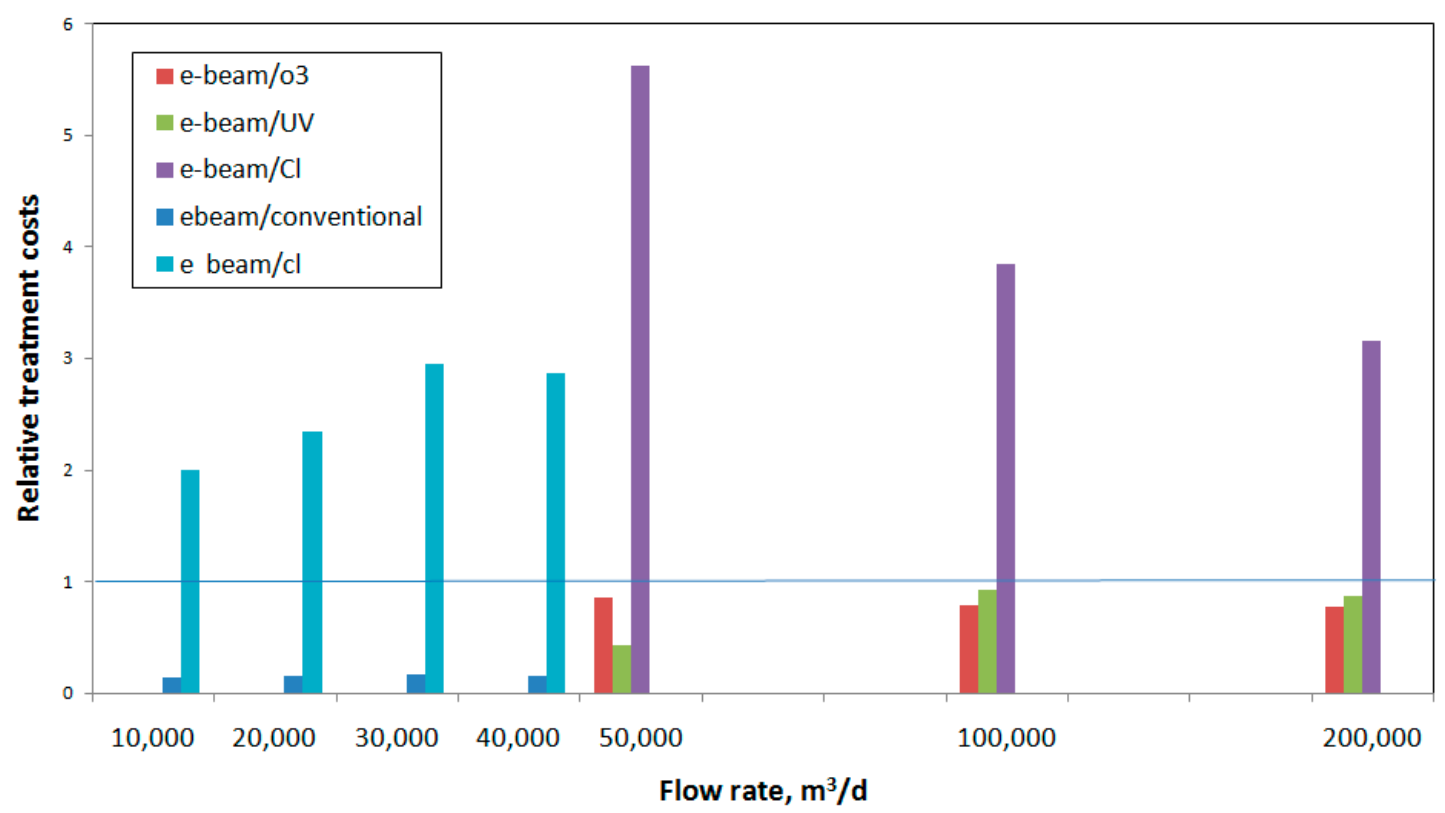

Figure 3. Relative treatment costs for wastewater using e-beam and other disinfection and conventional treatment methods $[48,64]$.

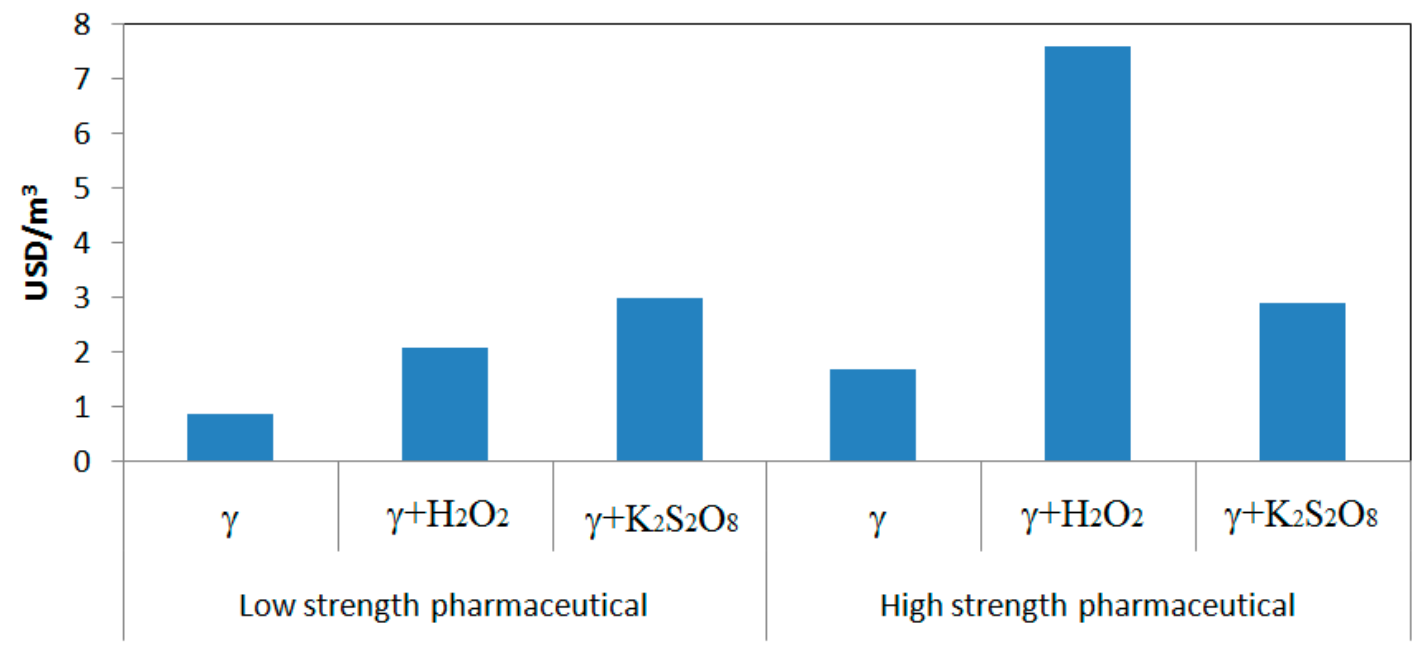

Figure 4. Treatment costs for $\gamma$ irradiation and combine coagulation- $\gamma$ irradiation [54].

There are some technical and non-technical issues that need to be resolved to ensure the sustainability of using this technology. These issues are listed below [22]

1. The usable output power of the electron accelerator limits its wide scale use as a safe substitute for chlorination for medium scale wastewater treatment plants.

2. Capital costs of electron accelerators needs to be reduced to ensure economical feasibility, where capital cost of installing an electron accelerator of $1 \mathrm{MeV} / 400 \mathrm{KW}$, could be attributed to half the accelerator price, whereas the design, construction, transportation, and installation of the facility contribute to $37.5 \%$ of capital cost.

From safety point of view, radiological accidents associated with different application of industrial irradiator, either $\gamma$ irradiators or accelerators are limited, and could be classified as level 4 on the international nuclear and radiological event scale (INES). This level is used to describe accident with local consequence; Figure 5 summarizes the radiological exposures in these historical accidents [65]. Except the 1967 accelerator accident, one worker was exposed to radiation in each accident with a 
probability 0.092 and $0.12 \mathrm{a}^{-1}$ for accelerators and $\gamma$ irradiators, respectively. It should be noted that due to the more stringent regulatory safety requirements that were issued later, similar accidents were not reported over three decades ago. These regulatory requirements are not only related to safety aspects but also to the security aspects to ensure the application of 3S concept (Safety, Security, and Safeguards) [66,67]. To reduce these accidents, and based on the national regulation, the following measures should be considered [68-70]:

1. Appropriate safety measures, i.e., shielding requirements, operational procedures, provision of safety assessment documents, should be applied to ensure radiological containments.

2. Appropriate security measures should be applied to ensure safety of workers and public.
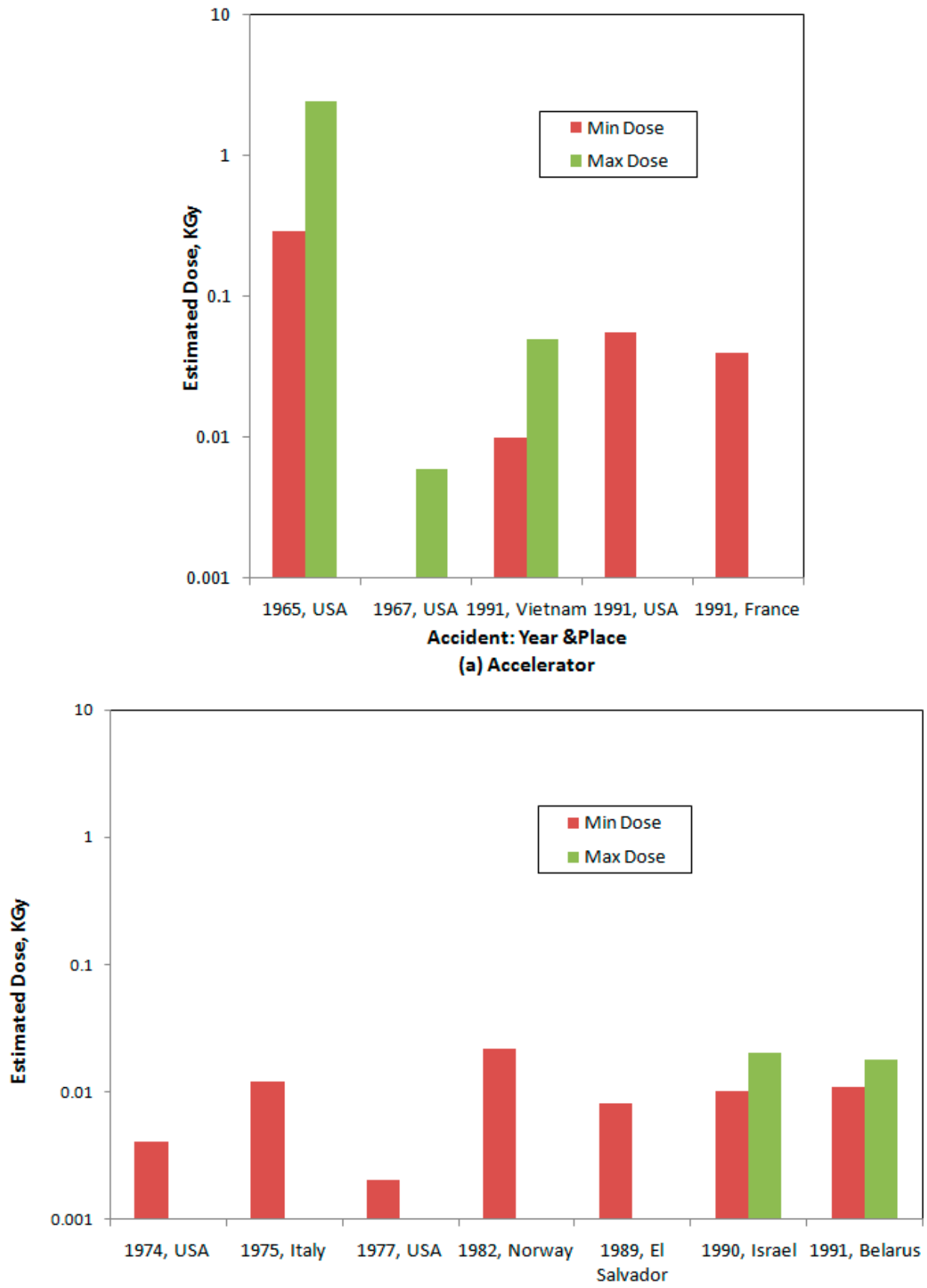

Accident: Year \&Place

(b) $\gamma$ Irradiator

Figure 5. Summary of the historical industrial irradiator accidents; (a) accelerators, (b) $\gamma$ irradiator. 
Currently, the control strategy in these facilities is based on the combination of physical protection means, i.e., shields, barriers, and interlocks, and operational procedures $[65,71]$. This strategy ensured an accident probability for industrial irradiator in the order of $2 \times 10^{-4} \mathrm{a}^{-1}$.

\section{Conclusions}

The review of ionizing radiation technology in decomposing bio-refractory organic contaminants and disinfecting different wastewater effluents were presented in this study. Factors that affect the sustainability of this technology were summarized. From this review the following conclusions could be drawn.

1. Most of the published work focused on the quantification of ionizing radiation effects on primary pollutants and the secondary intermediates toxicity, and determination of optimum irradiation conditions in different effluents. Research efforts are needed to study the feasibility of ionizing radiation treatment for petrochemical wastewater effluents,

2. Despite real industrial wastewater effluents were studied, there is a need to study the kinetics reactions in these complex systems to enable a better understanding and a better design for combined treatment schemes.

3. Compared to other disinfection technologies, the ionizing radiation technology provides economical, reliable, and safer operations that are not affected by the seasonal variation in the effluent composition, and reduces the generation of secondary toxic intermediates.

4. Operational safety of industrial irradiators has been improved due to the increasing stringent regulatory requirements and the updating the operational procedures, which lead to the reduction of accidents probability from $10^{-2}$ to $10^{-4} \mathrm{a}^{-1}$.

Author Contributions: Conceptualization, R.O.A.R. and Y.-T.H.; methodology, R.O.A.R.; resources, R.O.A.R. and Y.-T.H.; writing—original draft preparation, R.O.A.R.; writing—review and editing, R.O.A.R.; supervision, Y.-T.H.; funding acquisition, Y.-T.H. All authors have read and agreed to the published version of the manuscript.

Funding: This research received no external funding.

Conflicts of Interest: The authors declare no conflict of interest.

\section{References}

1. Allaoui, M.; Schmitz, T.; Campbell, D.; Porte, C.A.D.L. Good Practices, For Regulating Wastewater Treatment, Legislations, Policies and Standards; United Nations Environment Programme: Nairobi, Kenya, 2015.

2. UNESCAP. Policy Guidance Manual on Wastewater Management, with a Special Emphasis on Decentralized Wastewater Treatment Systems; UNESCAP: Bangkok, Thailand, 2015.

3. FAO. Wastewater Treatment and Use in Agricultural-FAO Irrigation and Drainage Paper 47; FAO: Rome, Italy, 1992; Available online: http://www.fao.org/3/t0551e/t0551e00.htm\#Contents (accessed on 20 November 2019).

4. Quach-Cu, J.; Herrera-Lynch, B.; Marciniak, C.; Adams, S.; Simmerman, A.; Reinke, R.A. The Effect of Primary, Secondary, and Tertiary Wastewater Treatment Processes on Antibiotic Resistance Gene (ARG) Concentrations in Solid and DissolvedWastewater Fractions. Water 2018, 10, 37. [CrossRef]

5. Deng, Y.; Zhao, R. Advanced Oxidation Processes (AOPs) in Wastewater Treatment. Curr. Pollut. Rep. 2015, 1, 167-176. [CrossRef]

6. Shon, H.; Vigneswaran, S.; Snyder, S. Effluent organic matter (EfOM) in wastewater: Constituents, effects, and treatment. Crit. Rev. Environ. Sci. Technol. 2006, 36, 327-374. [CrossRef]

7. Tchobanoglous, G.; Burton, F.L.; Stensel, H.D. Waste Water Engineering: Treatment and Reuse; Metcalf and Eddy: Wakefield, UK, 2003.

8. EU. Effluent Charging Systems in the EU Member States; European Parliament: Luxembourg, 2001.

9. Wastewater Treatment Requirement. Available online: https://www.lacsd.org/civicax/filebank/blobdload. aspx?blobid=3325 (accessed on 18 December 2019). 
10. Munter, R. Industrial wastewater characteristics. In Sustainable Water Management in the Baltic Sea Basin: Water Use and Management; Lundin, L.C., Ed.; The Baltic University Programme, Uppsala University: Uppsala, Sweden, 2000; pp. 185-194.

11. Kumar, M.; Puri, A. A review of permissible limits of drinking water. Indian J. Occup. Environ. Med. 2012, 16, 40-44. [PubMed]

12. WHO. A Compendium of Standards for Wastewater Reuse in the Eastern Mediterranean Region; WHO-EM/CEH/142/E; WHO: Cairo, Egypt, 2006.

13. Environmental Management Act. Municipal Wastewater Regulation B.C. Reg. 87/2012, Consolidation Current to 20 June2018. Available online: http://archives.leg.bc.ca/civix/document/id/crbc/crbc/87_2012 (accessed on 20 August 2019).

14. Councel Directive of 21 May 1991 Concerning Urban Wastewater Treatment (91/271/EEC). Available online: https://eur-lex.europa.eu/LexUriServ/LexUriServ.do?uri=OJ:L:1991:135:0040:0052:EN:PDF\%20 (accessed on 18 December 2019).

15. EU. Minimum Quality Requirements for Water Reuse in Agricultural Irrigation and Aquifer Recharge; Publications Office of the European Union: Luxembourg, 2017.

16. Luo, Y.; Guo, W.; Ngo, H.H.; Nghiem, L.D.; Hai, F.I.; Zhang, J.; Liang, S.; Wang, X.C. A review on the occurrence of micropollutants in the aquatic environment and their fate and removal during wastewater treatment. Sci. Total Environ. 2014, 473, 619-641. [CrossRef]

17. Naing, T.T.; Lay, K.K. Utilization of gamma radiation in industrial wastewater treatment. Int. J. Mech. Prod. Eng. 2015, 3, 1-5.

18. Miklos, D.B.; Remy, C.; Jekel, M.; Linden, K.G.; Drewes, J.E.; Hübner, U. Evaluation of advanced oxidation processes for water and wastewater treatment-A critical review. Water Res. 2018, 139, 118-131. [CrossRef]

19. Babu, D.S.; Srivastava, V.; Nidheesh, P.V.; Kumar, M.S. Detoxification of water and wastewater by advanced oxidation processes. Sci. Total Environ. 2019, 696, 133961. [CrossRef]

20. Liu, N.; Lei, Z.D.; Wanga, T.; Wang, J.J.; Zhang, X.D.; Xu, G.; Tang, L. Radiolysis of carbamazepine aqueous solution using electron beam irradiation combining with hydrogen peroxide: Efficiency and mechanism. Chem. Eng. J. 2016, 295, 484-493. [CrossRef]

21. Meng, M.; Pellizzari, F.; Boukari, S.O.B.; Leitner, N.K.V.; Teychene, B. Impact of e-beam irradiation of municipal secondary effluent on MF and RO membranes performances. J. Membr. Sci. 2014, 471, 1-8. [CrossRef]

22. IAEA. Radiation Treatment of Polluted Water and Wastewater; IAEA: Vienna, Austria, 2008.

23. Wojnarovits, L.; Takacs, E. Irradiation treatment of azo dye containing wastewater: An overview. Radiat. Phys. Chem. 2008, 77, 225-244. [CrossRef]

24. Sampa, M.H.O.; Takacs, E.; Gehringer, P.; Rela, P.R.; Ramirez, T.; Amro, H.; Trojanowicz, M.; Botelho, M.L.; Han, B.; Solpan, D.; et al. Remediation of polluted waters and wastewater by radiation processing. Nukleonika 2007, 52, 137-144.

25. Jan, S.; Kamili, A.N.; Parween, T.; Hami, R.; Parray, J.A.; Siddiqi, T.O.; Ahmad, M.P. Feasibility of radiation technology for wastewater Treatment. Desalin. Water Treat. 2015, 55, 2053-2068. [CrossRef]

26. Abdel Rahman, R.O.; Kozak, M.W.; Hung, Y.T. Radioactive pollution and control. In Handbook of Environment and Waste Management; Hung, Y.T., Wang, L.K., Shammas, N.K., Eds.; World Scientific Publishing Co: Singapore, 2014; pp. 949-1027. [CrossRef]

27. Gehringer, P. Advances in radiation processing of wastewater-Basics of the process. In Status of Industrial Scale Radiation Treatment of Wastewater and Its Future; IAEA-TECDOC-1407; IAEA: Vienna, Austria, 2003; pp. 7-17.

28. Shojaie, F. Comparison of the rate constants of a bimolecular reaction using two methods. Arab. J. Chem. 2017, 10, S148-S156. [CrossRef]

29. IAEA. Status of Industrial Scale Radiation Treatment of Wastewater and Its Future; IAEA-TECDOC-1407; IAEA: Vienna, Austria, 2003.

30. Wojnárovits, L.; Takacs, E. Wastewater treatment with ionizing radiation. J. Radioanal. Nucl. Chem. 2017, 311, 973-981. [CrossRef]

31. Chaychian, M.; Al-Sheikhly, M.; Silverman, J.; McLaughlin, W.L. The mechanisms of removal of heavy metals from water by ionizing radiation. Radiat. Phys. Chem. 1998, 53, 145-150. [CrossRef] 
32. Chmielewski, A.G. Application of ionizing radiation to environment protection. Nukleonika 2005, 50, s17-s24. [CrossRef]

33. Dalalia, N.; Kazeraninejada, M.; Akhavan, A. Removal of heavy metal ions from wastewater samples using electron beam radiation in the presence of $\mathrm{TiO}_{2}$. Desalin. Water Treat. 2017, 71, 136-144. [CrossRef]

34. El-Motaium, R.A. Application of nuclear techniques in Environmental studies and pollution Control. In Proceedings of the 2nd Environmental Physics Conference, Alexandria, Egypt, 18-22 February 2006; pp. 169-182.

35. Rela, P.R.; Sampa, M.H.O.; Duarte, C.L.; Costa, F.E.D.; Rela, C.S.; Borrely, S.I.; Mori, M.N.; Somessari, E.S.R.; Silveira, C.G. The status of radiation process to treat industrial effluents in Brazil. In Radiation Treatment of Polluted Water and Waste Water; IAEA TECDOC-1598; IAEA: Vienna, Austria, 2008; pp. 27-41.

36. Ramirez, T.; Armas, M.; Uzcategui, M. Effect of accelerated electron beam on pesticides removal of effluents from flower plantations. In Radiation Treatment of Polluted Water and Waste Water; IAEA TECDOC-1598; IAEA: Vienna, Austria, 2008; pp. 43-58.

37. Emmi, S.S.; De Paoli, G.; Takács, E.; Caminati, S.; Pálfi, T. The e-induced decomposition of pesticides in water: A gamma and pulse radiolysis investigation on carbofuran. In Radiation Treatment of Polluted Water and Waste Water; IAEA TECDOC-1598; IAEA: Vienna, Austria, 2008; pp. 77-88.

38. Şolpan, D. The degradation of some pesticides in aqueous solutions by gamma radiation. In Radiation Treatment of Polluted Water and Waste Water; IAEA TECDOC-1598; IAEA: Vienna, Austria, 2008; pp. 177-199.

39. Utrill, J.R.; Abdel Daiem, M.M.; Polo, M.S.; Pérez, R.O.; Peñalver, J.J.L.; Gala, I.V.; Mota, A.J. Removal of compounds used as plasticizers and herbicides from water by means of gamma irradiation. Sci. Total Environ. 2016, 569, 518-526. [CrossRef]

40. Sabbagh, S.; El Mahmoudi, A.S.; Al-Dakheel, Y.Y. Waste Water Sterilization by Cobalt Co-60 for the Agricultural Irrigation: A Case Study. Int. J. Water Resour. Arid Environ. 2014, 3, 11-18.

41. Lim, S.J.; Kim, T.H. Combined treatment of swine wastewater by electron beam irradiation and ion-exchange biological reactor system. Sep. Purif. Technol. 2015, 146, 42-49. [CrossRef]

42. Alkhuraiji, T.S.; Boukari, S.O.B.; Alfadhl, F.S. Gamma irradiation-induced complete degradation and mineralization of phenol in aqueous solution: Effects of reagent. J. Hazard. Mater. 2017, 328, 29-36. [CrossRef] [PubMed]

43. Sun, W.; Chen, L.; Tian, J.; Wang, J.; He, S. Degradation of a monoazo dye Alizarin Yellow GG in aqueous solutions by gamma irradiation: Decolorization and biodegradability enhancement. Radiat. Phys. Chem. 2013, 83, 86-89. [CrossRef]

44. Takacs, E.; Wojnarovits, L.; Palfi, T. Azo dye degradation by high-energy irradiation: Kinetics and mechanism of destruction. Nukleonika 2007, 52, 69-75.

45. Muneer, M.; Bhatti, I.A.; Bhatti, H.N.; Rehman, K.U. Treatment of Dyes Industrial Effluents by Ionizing Radiation. Asian J. Chem. 2011, 23, 2392-2394.

46. Abdou, L.A.W.; Hakeim, O.A.; Mahmoud, M.S.; El-Naggar, A.M. Comparative study between the efficiency of electron beam and gamma irradiation for treatment of dye solutions. Chem. Eng. J. 2011, 168, 752-758. [CrossRef]

47. Borrely, S.I.; Morais, A.V.; Rosa, J.M.; Pedroso, C.B.; Pereira, M.D.C.; Hig, M.C. Decoloration and detoxification of effluents by ionizing radiation. Radiat. Phys. Chem. 2016, 124, 98-202. [CrossRef]

48. Meibodi, M.E.; Parsaeian, M.R.; Amraei, R.; Banaei, M.; Anvari, F.; Tahami, S.M.R.; Vakhshoor, B.; Mehdizadeh, A.; FallahNejad, N.; Shirmardi, S.P.; et al. An experimental investigation of wastewater treatment using electron beam irradiation. Radiat. Phys. Chem. 2016, 125, 82-87. [CrossRef]

49. Deogaonkar, S.C.; Wakode, P.; Rawat, K.P. Electron beam irradiation post treatment for degradation of non biodegradable contaminants in textile wastewater. Radiat. Phys. Chem. 2019, 165, 108377. [CrossRef]

50. Basfar, A.A.; Abdel Rehim, F. Disinfection of wastewater from a Riyadh Wastewater Treatment Plant with ionizing radiation. Radiat. Phys. Chem. 2002, 65, 527-532. [CrossRef]

51. Lee, O.M.; Kim, H.Y.; Park, W.; Kim, T.H.; Yu, S. A comparative study of disinfection efficiency and regrowth control of microorganism in secondary wastewater effluent using UV, ozone, and ionizing irradiation process. J. Hazard. Mater. 2015, 295, 201-208. [CrossRef] [PubMed]

52. Sági, G.; Kovács, K.; Bezsenyi, A.; Csay, T.; Takács, E.; Wojnárovits, L. Enhancing the biological degradability of sulfamethoxazole by ionizing radiation treatment in aqueous solution. Radiat. Phys. Chem. 2016, 124, 179-183. [CrossRef] 
53. Tegze, A.; Sági, G.; Kovács, K.; Tótha, T.; Takács, E.; Wojnárovits, L. Radiation induced degradation of ciprofloxacin and norfloxacin: Kinetics and product analysis. Radiat. Phys. Chem. 2019, 158, 68-75. [CrossRef]

54. Changotra, R.; Rajput, H.; Guin, J.P.; Varshney, L.; Dhir, A. Hybrid coagulation, gamma irradiation and biological treatment of real pharmaceutical wastewater. Chem. Eng. J. 2019, 370, 595-605. [CrossRef]

55. Changotra, R.; Rajput, H.; Guin, J.P.; Khader, S.A.; Dhir, A. Techno-Economical Evaluation of Coupling Ionizing Radiation and Biological Treatment Process for the Remediation of Real Pharmaceutical Wastewater. J. Clean. Prod. 2020, 242, 118544. [CrossRef]

56. Chu, L.; Yu, S.; Wang, J. Gamma radiolytic degradation of naphthalene in aqueous solution. Radiat. Phys. Chem. 2016, 123, 97-102. [CrossRef]

57. Economical Aspects of Radiation Sterilization with Electron Beam. Available online: https://www.osti.gov/ etdeweb/servlets/purl/644045 (accessed on 18 December 2019).

58. Maruthi1, Y.A.; Das, N.L.; Hossain, K.; Rawat, K.P.; Sarma, K.S.S.; Sabharwal, S. Application of electron beam technology in improving sewage water quality: An advance technique. Eur. J. Sustain. Dev. 2013, 2, 1-18.

59. Hossain, K.Y.; Maruthi, A.; Das, N.L.; Rawat, K.P.; Sarma1, K.S.S. Irradiation of wastewater with electron beam is a key to sustainable smart/green cities: A review. Appl. Water Sci. 2018, 8, 6. [CrossRef]

60. Gala, I.V.; Peñalver, J.J.L.; Polo, M.S.; Utrilla, J.R. Degradation of X-ray contrast media diatrizoate in different water matrices by gamma irradiation. Chem. Technol. Biotechnol. 2013, 88, 1336-1343. [CrossRef]

61. Maruthi, A.Y.; Das, N.L.; Hossain, K.; Rawat, K.P.; Sarma, K.S.S.; Sabharwal, S. Disinfection and reduction of organic load of sewage water by electron beam radiation. Appl. Water Sci. 2011, 1, 49-56. [CrossRef]

62. Ndong, J.E.; Uribe, R.M.; Gregory, R.; Gangoda, M.; Nickelsen, M.G.; Loar, P. Effect of electron beam irradiation on bacterial and Ascaris ova loads and volatile organiccompounds in municipal sewage sludge. Radiat. Phys. Chem. 2015, 112, 6-12. [CrossRef]

63. IAEA. Radiation Technology for Cleaner Products and Processes; IAEA-TECDOC-1786; IAEA: Vienna, Austria, 2016.

64. Pereira, L.S.; Cordery, I.; Iacovides, I. Coping with Water Scarcity; IHP VI, Technical Documents in Hydrology 58; UNSCO: Paris, France, 2002.

65. Ortiz, P.; Oresegun, M.; Weatley, J. Lessons from Major Radiation Accidents. In Proceedings of the 10th International Congress of the International Radiation Protection Association-IRPA 10, Hiroshima, Japan, 14-19 May 2000.

66. IAEA. Management for the Prevention of Accidents from Disused Sealed Radioactive Sources; IAEA, TECDOC-1205; IAEA: Vienna, Austria, 2001.

67. Abdel Rahman, R.O. Introductory Chapter: Introduction to Current Trends in Nuclear Material Research and Technology. In Nuclear Material Performance; Abdel Rahman, R.O., Saleh, H.E.M., Eds.; Intech: Rijeka, Croatia, 2016; pp. 3-14. Available online: http://www.intechopen.com/books/nuclear-material-performance/ introductory-chapter-introduction-to-current-trends-in-nuclear-material-research-and-technology (accessed on 18 December 2019).

68. USDOE. Safety of Accelerator Facilities; DOE O440.C; USDOE: Washington, DC, USA, 2011.

69. IAEA. Directory of Gamma Processing Facilities in Member States; IAEA-DGPF/CD; IAEA: Vienna, Austria, 2004.

70. IAEA. Radiation Safety of Gamma, Electron and X Ray Irradiation Facilities; SSG No. 8; IAEA: Vienna, Austria, 1996.

71. Janžekovič, H. Overview of Radiation Accidents at Industrial Accelerator Facilities. In Proceedings of the 26th International Conference on Nuclear Energy for New Europe, NENE, Bled, Slovenia, 11-14 September 2017; p. 7.

(C) 2019 by the authors. Licensee MDPI, Basel, Switzerland. This article is an open access article distributed under the terms and conditions of the Creative Commons Attribution (CC BY) license (http://creativecommons.org/licenses/by/4.0/). 